\title{
Consumer Behaviour in the Accommodation Services Market - a Comparison of Vienna, Bratislava and Prague in 2018
}

\author{
Martin Petříček (iD) https://orcid.org/0000-0002-0816-2325 \\ Ph.D., Ing. / Assistant professor, Institute of Hospitality Management \\ Prague, Czech Republic, e-mail: petricek@vsh.cz \\ Štěpán Chalupa (iD https://orcid.org/0000-0002-1612-9242 \\ Ing. / PhD candidate, University of Hradec Králové \\ Hradec Králové, Czech Republic, e-mail: chalupa@vsh.cz
}

\section{Abstract}

The paper aims to compare three accommodation services markets using empirical data from more than 250 accommodation facilities in specific destinations (Vienna, Bratislava, Prague). The data are available on a daily basis, but the resulting comparison is then performed on a monthly basis within 2018. The comparison is performed based on three basic criteria - occupancy, average daily rate and an indicator of price elasticity of demand. Price elasticity is measured using a log-log regression analysis. The key findings of the comparison are as follows: (1) The Vienna and Prague markets are similar in terms of occupancy and coefficient of price elasticity. In contrast, the Bratislava market showed statistically significant differences from the other two markets in all the criteria under review. (2) The Bratislava market operates at a significantly lower price range compared to the other markets analysed. In the long term, this market has also been lower in the field of occupancy. (3) The markets in Vienna and Prague respond more dynamically to changes in consumer behaviour by changing prices. (4) The so-called "November Phenomenon" has been identified, where all indicators in all markets behave unconventionally. (5) All markets have in common the fact that they have shown price-inelastic demand over the long term, and at the turn of the year, they all face Giffen's paradox.

Keywords: accommodation service, consumer behaviour, price elasticity, Vienna, Bratislava, Prague

JEL: D12, O14 


\section{Introduction}

The competitiveness of tourism destinations is one of the critical areas of tourism research (Ivanov and Webster 2013; Dorta-Afonso and Hernández-Martín 2015). For our comparison, we used TTCI (Tourism and Travel Competitiveness Index), which considers four areas of destination evaluation, namely destination infrastructure, national tourism policy setting, natural and cultural resources, as well as the state environment itself. One of the key areas for assessing the competitiveness of destinations is the hotel industry (Ivanov and Ivanova 2016).

If we focus on comparing the hotel market environment, most of the previous studies mainly examined the competitiveness (efficiency comparison) of companies (hotels and restaurants) in a given market. Kim and Kim (2005) confirmed the competitive advantage represented by a strong brand. Akbaba (2006) and Reynolds and Thompson (2007) investigated the impact of customer satisfaction on the overall quality of services. Nunes, Estevao and Nicolau Filipe (2018) use Porter's model to identify the main factors in the field of competitiveness of accommodation providers, including cooperation and innovation, business environment characteristics, and the state of interconnected and supportive industries. Baldassin, Gallo and Mattevi (2015) compared the quality and scope of services provided and the characteristics of destinations for 26 European countries. Xia et al. (2018) used user-created content (reviews and ratings) to compare individual accommodation facilities and assess their competitiveness. Others (Barros 2005; Sanjeev 2007) used economic models to compare accommodation facilities.

One of the widely used methods of economic comparison is the input-output DEA model (Sigala 2004; Wang, Hung, and Shang 2006; Hsieh and Lin 2010). Sanjeev (2007) compared hotels and restaurants based on book values using the values of fixed and total assets, operating costs and equity. The output was then total income and profit before and after taxation. Barros and Dieke (2008) used the total cost and investment cost, which they linked to the RevPAR indicator. Assaf, Barros and Josiassen (2010) examined 78 hotels in Taiwan with a focus on their quantitative characteristics, such as the total number of rooms, the entire staff of each department (booking, food and beverage and aggregated from all other departments) and the main outputs in terms of total accommodation, restaurant and a supplementary income, occupancy and number of customers per employee.

The same method was used by Mendieta-Peñalver et al. (2016), who focused on combining the DEA model and Mediation model. They used a larger number of indicators in the analysis and, in addition to the hotel efficiency indicators (total revenues, RevPAR, labour costs, number of employees, the total number of rooms), they also used the TTCI tourism destination competitiveness indicator and the market share of individual companies. The authors pointed to a close link between the performance of accommodation facilities and their efficiency with the overall performance of tourism destinations and their competitiveness. Other authors point to the close links between the performance of tourism and the hotel industry (Dioko and So 2012; Ivanov and Ivanova 2016). 
Most authors emphasise the need to take into account a number of comparative factors, such as the type of customer and their behaviour. Customers' behaviour in relation to the performance of accommodation facilities, i.e. in the sense that it relates to the performance of a tourist destination, is addressed by the authors in the field of revenue management (Vives, Jacob, and Aquiló 2018; Abrate, Nicolau, and Viglia 2019). Sánchez-Pérez, Illescas-Manzano, and Martínez-Puertas (2019) identified the main factors affecting the pricing of accommodation, which include hotel characteristics, electronic word-of-mouth, the level of competition, but also the destination itself.

For customers' behaviour, the most important aspect is their willingness to pay the highest available price set by the accommodation operator. In a dynamic environment, this willingness is expressed in the coefficient of price elasticity of demand, which shows the percentage change in the demanded quantity in relation to the percentage change in the price of a given hotel or destination (Shy 2008; Vives, Jacob, and Aquiló 2018).

The aim of the article is to compare individual markets and identify key differences in consumer behaviour based on the measured coefficient of price elasticity of demand for accommodation services. The comparison itself is based on three criteria: occupancy rate, average price and coefficient of price elasticity of demand. All these criteria are calculated and measured based on market data from nearly 250 accommodation facilities in the individual cities under review. The comparison was carried out monthly during 2018 to better reflect the seasonality that is typical for the accommodation sector.

\section{Methodology}

The following part of the article briefly describes the methodological approaches that are used to achieve the main objective of the article, which is aimed at comparing individual markets. However, we will first focus on a brief description of the data used. Given the issue addressed by this paper, it is crucial to have the appropriate data available to interpret the behaviour of individual markets correctly. Long-term cooperation with STR Global Inc., which collects data from hotels in relevant markets, is key to ensuring appropriate data. In this respect, this article can be considered unique because of the fact that the data it contains represent data taken from nearly 250 accommodation facilities from the monitored sites. The uniqueness of these data lies mainly in the fact that it is extracted on a daily basis. In total, there are several thousand pieces of data available, which have been processed in such a way that the outputs can be properly interpreted.

For the comparison itself (which is evaluated based on paired t-tests), three indicators have been chosen that are used in the accommodation sector and which appropriately reflect how consumers make their choices. First of all, we calculate occupancy of individual accommodation capacities, then the average price, and last but not least 
(which can be considered another key result of this contribution), we measure the coefficient of price elasticity of demand in the monitored markets.

The occupancy $(\mathrm{Occ})$ indicator is generally used in the analysis of accommodation capacities relatively commonly. Current use can be found, for example, in studies for SMEs - Small and medium-sized enterprises (Nalley, Park, and Bufquin 2019; Tembi and Kimbu 2019). The occupancy calculation itself is given as formula (1).

$$
\text { Occ }=\frac{\text { total rooms sold }}{\text { total rooms available for sale }} \times 100 \text {. }
$$

The second indicator, which is a criterion for comparison, is the ADR (Average Daily Rate). It is basically an indicator that represents the current average price. It is calculated according to the relation shown below (formula 2)

$$
A D R=\frac{\text { total rooms revenue }}{\text { total rooms sold }}
$$

Another approach and criterion is the coefficient of price elasticity. Price elasticity is an element of economic theory that combines more advanced analytical tools and classical consumer behaviour based on classical political economy. The first references to the elasticity of demand can be found in Mill. He played an important role in shaping price theory, and he was the one who, in examining the impact of price change on consumer spending, distinguished demand as elastic, inelastic and unit elastic in terms of price. Alfred Marshall, however, made a precise definition of how to quantify the price elasticity of demand. This knowledge could then be used to understand elasticity as an element that helps to understand the behaviour not only of the demand part but of the market as a whole. Current approaches to measuring elasticity include, for example, the approach combining the effect of an Exchange rate with price elasticity (Aalen, Iversen, and Jakobsen 2019) or the approach focused on measuring the so-called cross-price elasticity (Ahn et al. 2018). This article will perform the calculation using a log-log regression analysis. Thus, we will determine the empirical regression function in the form:

$$
\log Q_{i}=b_{0}+b_{1} \times \log P_{i}+e_{i}
$$

The estimation of individual parameters will be performed using the Ordinary least squares (OLS) method. The model used will be applied assuming ceteris paribus, which can be expressed as:

$$
\text { if } \Delta \varepsilon=0 \text { than } \Delta y=\beta_{1} \times \Delta x \text {. }
$$

Also, we only address the effect of one component (beta coefficient 1 ) on the size of component yi, i.e. the value of the quantity demanded. Coefficient $\beta 1$, or more pre- 
cisely, estimated parameter bl, represents the price change. Therefore, the aforementioned restriction is carried out. In addition to the above assumption, the whole model is then handled under the following condition:

$$
\sum_{i=1}^{n} e_{i}^{2}=\sum_{i=1}^{n}\left(\log Q_{i}-b_{0}-b_{1} \log Q_{i}\right)^{2} \ldots \min .
$$

It is, therefore, a search for the local extreme of a function, which we call Q, and it looks as follows:

$$
Q=\sum_{i=1}^{n}\left(\log Q_{i}-b_{0}-b_{1} \times \log Q_{i}\right)^{2}
$$

The overall solution is, therefore based on the following assumptions (7) and (8):

$$
\begin{aligned}
& \frac{d Q}{d b_{0}}=2 \sum_{i=1}^{n}\left(\log Q_{i}-b_{0}-\log P_{1 i} \times b_{1}\right) \times(-1)=0, \\
& \frac{d Q}{d b_{1}}=2 \sum_{i=1}^{n}\left(\log Q_{i}-b_{0}-\log P_{1 i} \times b_{1}\right) \times\left(-x_{i}\right)=0 .
\end{aligned}
$$

The model used will be tested at several levels. First, the regression parameters of the model are tested based on the t-test. The quality of the whole regression model is always measured by the coefficient of determination (R2) and thus by the relation:

$$
R^{2}=\frac{\sum_{j=1}^{n}\left(\widehat{y_{j}}-\bar{y}\right)^{2}}{\sum_{j=1}^{n}\left(y_{j}-\bar{y}\right)^{2}}
$$

The final price elasticity coefficient of demand is then identical to the value of parameter b1. The results of the calculation of elasticity are presented in Table 1.

Table 1. Coefficient of price elasticity

\begin{tabular}{|c|c|}
\hline Epd & Demand \\
\hline$E_{p d}=|1|$ & Unit elasticity \\
\hline$E_{p d}>0$ & Giffen's paradox \\
\hline$E_{p d}<0$ & Negative price elasticity \\
\hline$-1<E_{p d}<0$ & Inelastic demand \\
\hline$-\infty<\mathrm{E}_{\mathrm{pd}}<-1$ & Elastic demand \\
\hline
\end{tabular}

Source: own processing. 


\section{Results}

The analysis carried out focuses on the situation on the market of accommodation services of the capitals of Austria, Slovakia and the Czech Republic. As part of this research, data were collected for 2018 on a monthly basis with a view to better evaluating individual outputs. The monthly basis was chosen mainly because it is more appropriate to show the seasonality of individual markets and thus different consumer behaviour. Any insight into the problem is made from the point of view of consumer behaviour. First, it is the willingness of consumers to provide accommodation services on the basis of measuring the occupancy of individual destinations. Second, it is a comparison based on an average price paid (measured by the Average Daily Rate; ADR). Third, it is a comparison based on the measured price elasticity of demand. Individual outputs are presented in the following text.

In this part of the text, we will focus on comparing the above three markets based on occupancy first. Occupancy of individual destinations as its average monthly value is shown in Table 2. Then, in Table 3, you can see basic descriptive statistics of individual markets.

Table 2. Occupancy (\%)

\begin{tabular}{|l|c|c|c|c|c|c|c|c|c|c|c|c|}
\hline \multicolumn{1}{|c|}{ Month } & $\mathbf{1}$ & $\mathbf{2}$ & $\mathbf{3}$ & $\mathbf{4}$ & $\mathbf{5}$ & $\mathbf{6}$ & $\mathbf{7}$ & $\mathbf{8}$ & $\mathbf{9}$ & $\mathbf{1 0}$ & $\mathbf{1 1}$ & $\mathbf{1 2}$ \\
\hline Vienna & 52 & 57 & 69 & 81 & 82 & 86 & 80 & 85 & 87 & 86 & 82 & 85 \\
\hline Bratislava & 54 & 56 & 60 & 72 & 73 & 73 & 62 & 68 & 76 & 73 & 65 & 62 \\
\hline Prague & 53 & 59 & 75 & 82 & 85 & 85 & 86 & 90 & 88 & 87 & 76 & 80 \\
\hline
\end{tabular}

Source: own processing.

Table 3. Basic statistics indicators of occupancy

\begin{tabular}{|l|c|c|c|c|}
\cline { 2 - 5 } \multicolumn{1}{c|}{} & Mean & Minimum & Maximum & Std. Dev. \\
\hline Vienna & 77.59 & 51.70 & 86.60 & 11.87 \\
\hline Bratislava & 66.15 & 53.90 & 75.60 & 7.35 \\
\hline Prague & 78.68 & 53.00 & 89.60 & 11.62 \\
\hline
\end{tabular}

Source: own processing.

The above data show that Bratislava has shown the lowest value in the long term, but we can find the overall minimum value in Vienna. The situation is similar in terms of maximum occupancy rates in individual markets. This also corresponds to the highest value of the standard deviation of Vienna, while the minimum values can be found in the Bratislava market. For ease of reference, occupancy data in individual markets are also shown in the form of Box Plot (Figure 1). 


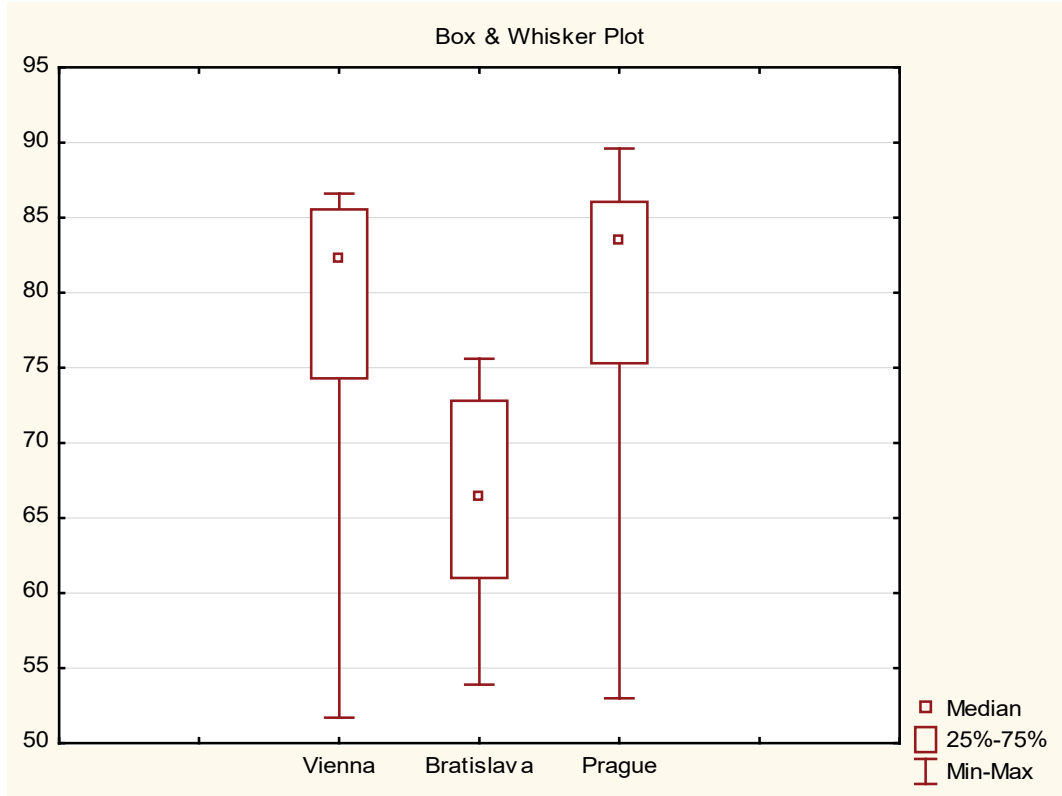

Figure 1. Box Plot of Occupancy

Source: own processing.

The question remains whether these differences in individual markets are statistically significant. Hypothesis testing will be performed to answer this question. After performing the normality test, the two-value-match hypothesis test can be used using a paired t-test based on two independent selections. These paired tests are always performed in triplicate to test the relationship between all three markets. The following hypotheses (where index $\mathrm{V}$ denotes Vienna, index B denotes Bratislava, and index P denotes Prague, $\mu$ denotes median occupancy) will be tested at the $5 \%$ significance level:

$$
\begin{aligned}
& \mathrm{H}_{0}: \mu_{\mathrm{V}}-\mu_{\mathrm{B}}=0 \\
& \mathrm{H}_{\mathrm{A}}: \mu_{\mathrm{V}}-\mu_{\mathrm{B}}>0 \\
& \mathrm{H}_{0}: \mu_{\mathrm{V}}-\mu_{\mathrm{P}}=0 \\
& \mathrm{H}_{\mathrm{A}}: \mu_{\mathrm{V}}-\mu_{\mathrm{P}} \neq 0 \\
& \mathrm{H}_{0}: \mu_{\mathrm{P}}-\mu_{\mathrm{B}}=0 \\
& \mathrm{H}_{\mathrm{A}}: \mu_{\mathrm{P}}-\mu_{\mathrm{B}}>0
\end{aligned}
$$

Below, the outputs of testing individual null and alternative hypotheses will be assessed. First, we focus on the first pair, i.e. comparing the Vienna and Bratislava markets. The established hypotheses are designed to test the claim that the occupancy rate in the Vienna market is higher than in the Bratislava market. Based on the performed test, it is then determined that based on $\mathrm{p}$-value $=0.009567$, which is lower than 0.05 , we reject the null hypothesis in favour of the alternative hypothesis. It can, therefore, be argued that there was a statistically significant difference in occupancy 
rates in the Vienna and Bratislava markets, with the occupancy rate being considered higher in Vienna.

Another comparison took place on the Vienna and Prague markets. At first glance, this market shows very similar results, so the outcome of hypothesis testing will more accurately determine whether these small differences can be considered significant. Alternatively, the hypothesis assumes that there are statistically significant differences (a two-way test). Based on the calculations made and the $\mathrm{p}$-value $=0.8220$, it is necessary not to reject the null hypothesis at the $5 \%$ level of significance, and it cannot be argued that the occupancy rates in Vienna and Prague are different.

The third comparison will focus on the markets in Prague and Bratislava. Within the hypothesis, we focus on whether the lower occupancy rate in Bratislava is statistically significant compared to the occupancy rate in Prague. Based on the calculations made when $p$-value $=0.00457$, at the $5 \%$ level of significance, we reject the null hypothesis, and it can, therefore, be argued that when comparing the market in Prague and Bratislava, the lower occupancy on the Bratislava market is statistically understood as significant. Similar testing is also performed using calculated ADR values and the price elasticity of demand. The outputs are presented below.

This part of the paper focuses on comparisons based on ADR, which we could compare to the average price for accommodation services expressed as its daily value. All numbers are in euros. The following Table 4 and Table 5 represent the aggregated calculated data for each market on a monthly basis.

Table 4. Average Daily Rate (EUR)

\begin{tabular}{|l|c|c|c|c|r|r|r|r|r|r|r|r|}
\hline \multicolumn{1}{|c|}{ Month } & 1 & 2 & 3 & 4 & 5 & \multicolumn{1}{c|}{6} & $\mathbf{7}$ & $\mathbf{8}$ & 9 & 10 & 11 & 12 \\
\hline Vienna & 88 & 92 & 88 & 97 & 104 & 106 & 90 & 91 & 117 & 115 & 101 & 125 \\
\hline Bratislava & 65 & 64 & 65 & 67 & 72 & 70 & 63 & 62 & 72 & 72 & 67 & 69 \\
\hline Prague & 73 & 67 & 74 & 95 & 105 & 101 & 92 & 86 & 104 & 99 & 77 & 93 \\
\hline
\end{tabular}

Source: own processing.

Table 5. Basic statistics indicators of Average Daily Rate

\begin{tabular}{|l|c|c|c|c|}
\cline { 2 - 5 } \multicolumn{1}{c|}{} & Mean & Minimum & Maximum & Std. Dev. \\
\hline Vienna & 101.05 & 87.50 & 124.80 & 12.58 \\
\hline Bratislava & 67.34 & 61.99 & 71.93 & 3.56 \\
\hline Prague & 88.89 & 66.91 & 105.05 & 13.17 \\
\hline
\end{tabular}

Source: own processing.

If we focus on $\mathrm{ADR}$, it is obvious that the highest levels are achieved in the market in Vienna, then in Prague, and the lowest values can be seen in Bratislava. Interestingly, the market in Bratislava shows a much lower standard deviation than the other two markets, and this refers to the fact that prices in this market are much less dynamic than in the other two markets. For a more straightforward interpretation of the outputs described above, these are also shown in the Box Plot in Figure 2. 


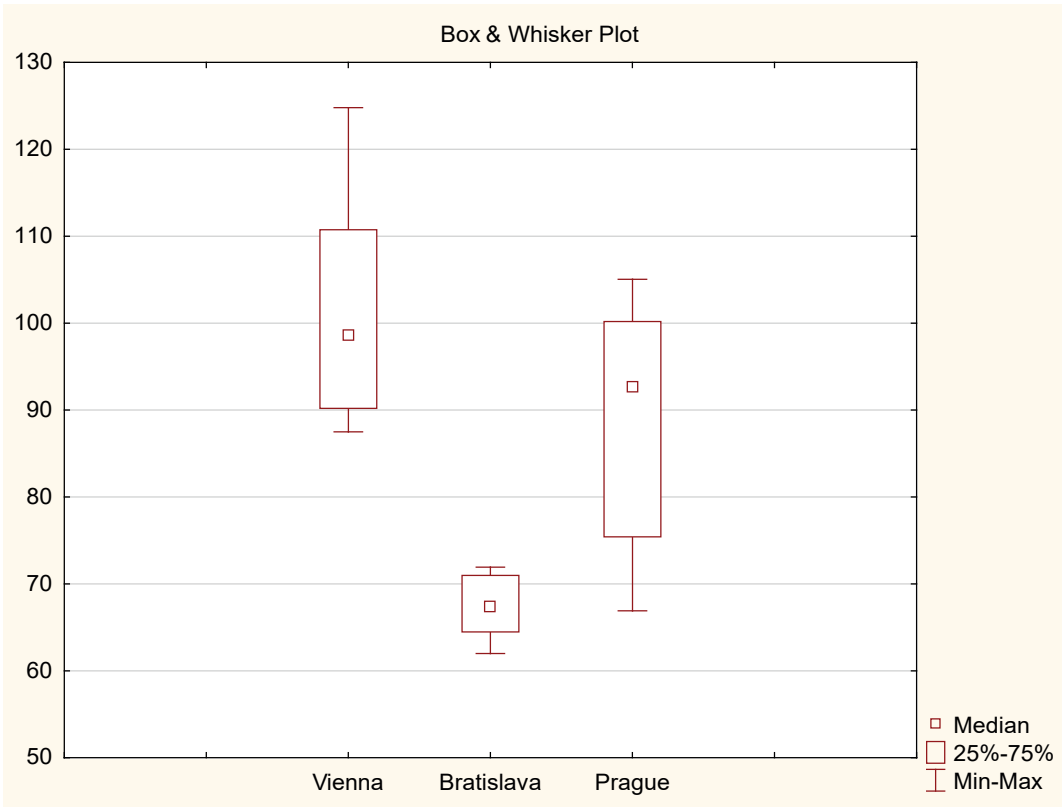

Figure 2. Box Plot of ADR

Source: own processing.

The differences described above are then similarly tested as in the case of occupancy to show the differences between the markets. Again, three pairs of markets are tested in such a way as to obtain comprehensive outputs. Tests (after checking the normality of distributions of a given quantity) run at a $5 \%$ significance level and test the following hypotheses (where index $\mathrm{V}$ represents data for Vienna, index B data for Bratislava and index $P$ data for Prague; $\pi$ represents the mean of ADR):

$\mathrm{H}_{0}: \pi_{\mathrm{V}}-\pi_{\mathrm{B}}=0$

$\mathrm{H}_{\mathrm{A}}: \pi_{\mathrm{V}}-\pi_{\mathrm{B}}>0$

$\mathrm{H}_{0}: \pi_{\mathrm{V}}-\pi_{\mathrm{P}}=0$

$\mathrm{H}_{\mathrm{A}}: \pi_{\mathrm{V}}-\pi_{\mathrm{P}} \neq 0$

$\mathrm{H}_{0}: \pi_{\mathrm{P}}-\pi_{\mathrm{B}}=0$

$\mathrm{H}_{\mathrm{A}}: \pi_{\mathrm{P}}-\pi_{\mathrm{B}}>0$

Now we will focus on evaluating individual hypotheses. The first pair tested was Vienna and Bratislava. With a p-value $=0.0001$, we clearly reject the null hypothesis, and we can confirm that at the 5\% significance level, the claim that the ADR in Vienna is higher than the ADR in Bratislava is correct (even with a much higher probability than 95\%). The second pair compared was Vienna and Prague. Here, the Box Plot shows that these are similar markets, with Prague reaching basically a lower value. Nevertheless, the hypothesis was established as a two-way test. Based on the calculations performed and a p-value $=0.0305$, the null hypothesis in favour of the alternative hypothesis can also be rejected. However, it is obvious that this testing is not as clear 
as in the case of the market comparison in Vienna and Bratislava above. The third pair compared was the situation in Prague and Bratislava. Like the comparison of Vienna and Bratislava, there are significant differences in prices, as evidenced by the statistical test. On the basis of the p-value $=0.0001$, we reject the null hypothesis in favour of the alternative hypothesis.

The last criterion under consideration in the three markets is the coefficient of price elasticity of demand. This coefficient was determined based on the log-log regression functions - a total of 36 were created. The results of these calculated elasticities are presented in Table 6 and Table 7 below.

Table 6. Coefficients of price elasticity of demand

\begin{tabular}{|l|c|c|c|c|c|c|c|c|c|c|c|c|}
\hline \multicolumn{1}{|c|}{ Month } & $\mathbf{1}$ & $\mathbf{2}$ & $\mathbf{3}$ & $\mathbf{4}$ & $\mathbf{5}$ & $\mathbf{6}$ & $\mathbf{7}$ & $\mathbf{8}$ & $\mathbf{9}$ & $\mathbf{1 0}$ & 11 & 12 \\
\hline Vienna & 0.4 & -0.5 & -0.3 & -0.5 & -0.3 & -0.2 & -0.1 & -0.3 & -0.3 & -0.3 & -1.1 & -0.1 \\
\hline Bratislava & -1.2 & -0.9 & -1.5 & -0.1 & -0.3 & -1.4 & -1.5 & -0.5 & -0.4 & -0.1 & -1.0 & 0.2 \\
\hline Prague & 0.3 & -0.3 & -0.3 & -0.1 & -0.1 & -0.5 & -0.1 & -0.2 & -0.1 & -0.1 & -1.0 & 0.3 \\
\hline
\end{tabular}

Source: own processing.

Table 7. Basic statistics indicators of the coefficients of price elasticity of demand

\begin{tabular}{|l|c|c|c|c|}
\hline & Mean & Minimum & Maximum & Std. Dev. \\
\hline Vienna & -0.29 & -1.10 & 0.43 & 0.36 \\
\hline Bratislava & -0.72 & -1.51 & 0.21 & 0.60 \\
\hline Prague & -0.18 & -1.06 & 0.34 & 0.36 \\
\hline
\end{tabular}

Source: own processing.

Based on the above figures, it is evident that in all three markets, the so-called Giffen's paradox is identified, in which the value of price elasticity of demand is positive. These non-standard situations are typically present in January and December, i.e. at a period that is always outside traditional values in terms of accommodation services due to the turn of the year. Interestingly, however, is the unequivocal increase in negative elasticity in November in all three markets. This increase also corresponds to the decline in average prices in this period. Based on analysis from other years, it can be argued that this phenomenon occurs regularly in all three markets. To simplify the interpretation of the value, the development is supplemented with a graphical representation, which is presented in Figure 3.

To complete the overview, we also show a Box Plot that presents the whole situation on the three markets monitored in 2018 much better. The output is presented in Figure 4. The numbers in Table 7 also point to the fact that the standard deviation values for the Bratislava market are almost double. This also corresponds to Figure 3. 


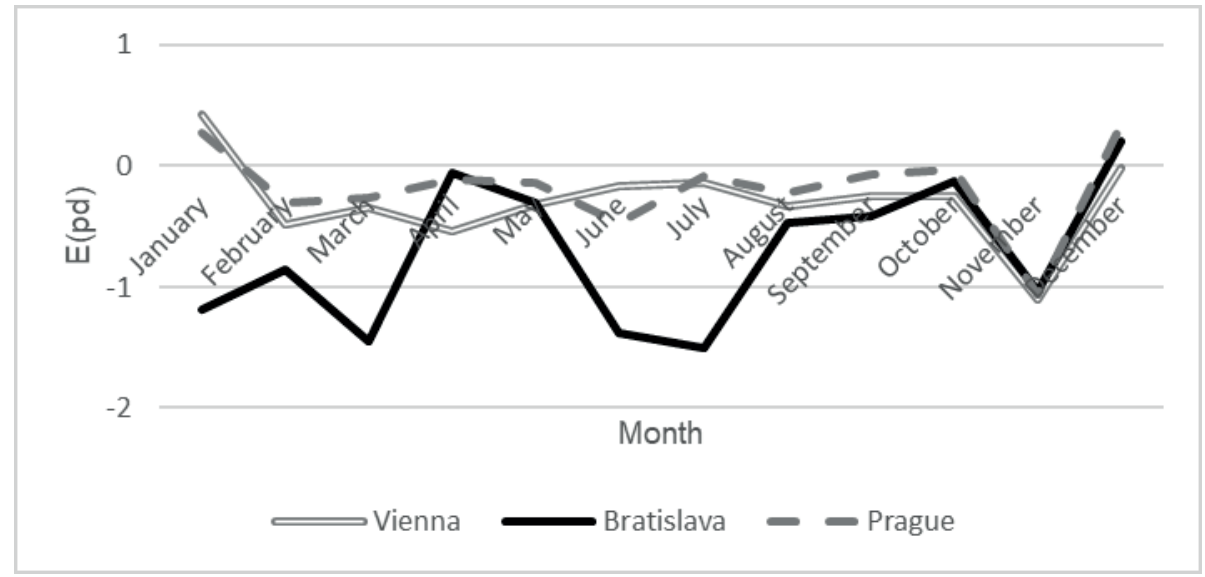

Figure 3. Development of price elasticity

Source: own processing.

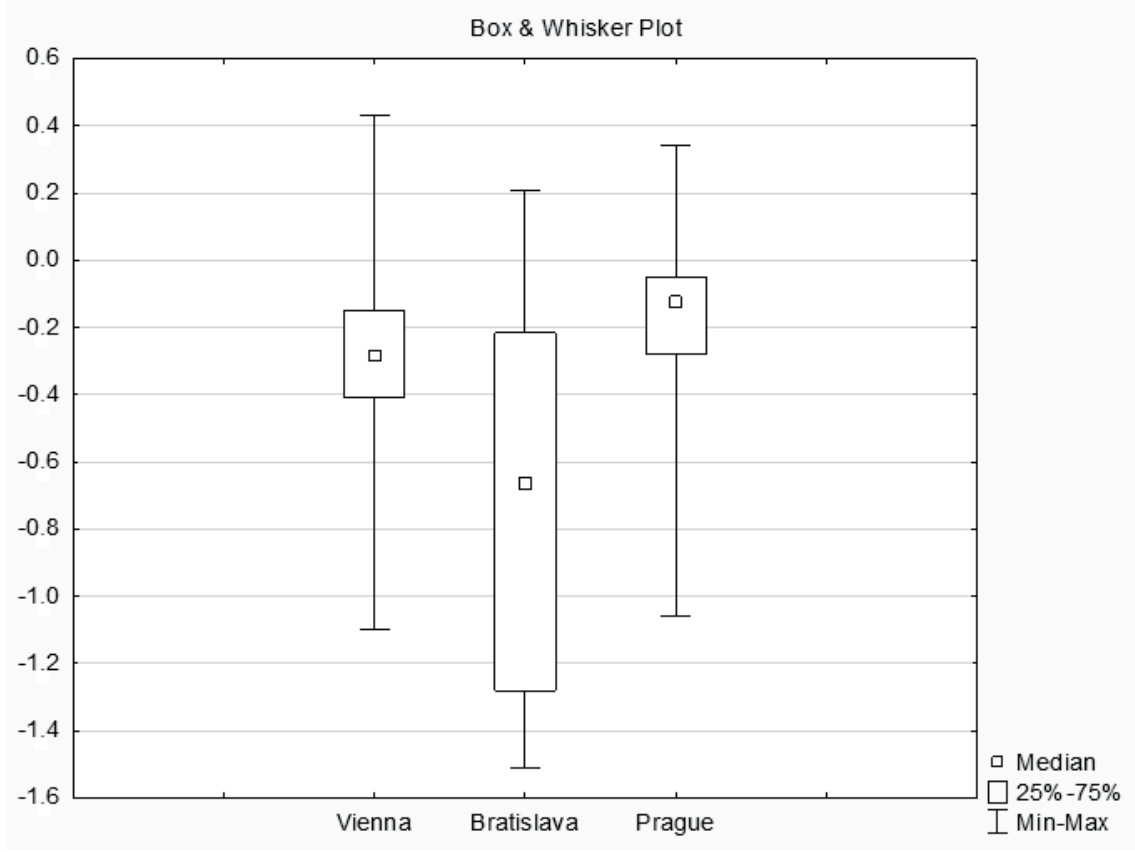

Figure 4. Box Plot of price elasticities

Source: own processing.

As well as with Occupancy and ADR, tests will be carried out to determine if there are statistically significant differences between the markets under review. Based on several studies (Goolsbee and Petrin 2004; Morlotti et al. 2017), it can be assumed that 
elasticity also has a normal distribution, and therefore paired t-tests will be performed similarly to the previous cases. New hypotheses will be determined to be tested again (where index $\mathrm{V}$ denotes data for Vienna, index B data for Bratislava and index $\mathrm{P}$ data for Prague; $\rho$ denotes the mean value of elasticity).

$$
\begin{aligned}
& \mathrm{H}_{0}: \rho_{\mathrm{V}}-\rho_{\mathrm{B}}=0 \\
& \mathrm{H}_{\mathrm{A}}: \rho_{\mathrm{V}}-\rho_{\mathrm{B}} \neq 0 \\
& \mathrm{H}_{0}: \rho_{\mathrm{V}}-\rho_{\mathrm{P}}=0 \\
& \mathrm{H}_{\mathrm{A}}: \rho_{\mathrm{V}}-\rho_{\mathrm{P}} \neq 0 \\
& \mathrm{H}_{0}: \rho_{\mathrm{P}}-\rho_{\mathrm{B}}=0 \\
& \mathrm{H}_{\mathrm{A}}: \rho_{\mathrm{P}}-\rho_{\mathrm{B}} \neq 0
\end{aligned}
$$

First, the Vienna and Bratislava markets are compared again. Based on the calculated p-value $=0.0455$, we reject the null hypothesis, and at the $5 \%$ significance level, the differences in elasticity were shown to be significant. However, the p-value does not reach unambiguously low values, and we would not reject the null hypothesis at a lower level of significance. When comparing the Vienna and Prague markets, based on the price elasticity of demand, we get a p-value $=0.4456$, and on this basis, we do not reject the null hypothesis. It can be argued that the values of price elasticity in the markets in Prague and Vienna are similar. The conclusion, which is based on the comparison of the Prague and Bratislava markets, is similar to the difference between the Vienna and Bratislava markets. The result of the p-value $=0.0136$ leads to the rejection of the null hypothesis and to the claim that the price elasticities of the two markets are different.

\section{Conclusion}

It can be argued that the comparison of occupancy of individual markets holds true that the Vienna and Bratislava markets show demonstrable differences, as well as the market pair Prague and Bratislava. On the other hand, a comparison of the Vienna and Prague markets shows that the occupancy differences have not been established and it can, therefore, be argued that these markets function similarly in terms of occupancy.

The second criterion tested was ADR, which is basically an average price. Based on the tests carried out, it has been shown that the price differs between all pairs, and thus it can be argued that the price is different across the markets examined. However, this conclusion does not indicate that these markets operate differently. Rather, it points to different price levels in economies in general. A more detailed description of the price differences is described later in this chapter.

The third test criterion was the calculated value of price elasticity of demand - it shows here that the same fact applies as in case of occupancy. Between the Vienna and Bratislava markets, as well as between Prague and Bratislava, there were statistically significant differences in the mean elasticity values. By contrast, in the 
pair of Vienna and Prague, the null hypothesis of the same functioning of the market was not rejected, and it can, therefore, be argued that in terms of price elasticity, these markets (or consumers) are very similar in behaviour.

On the basis of the analysis carried out, other conclusions that follow from the research are observable. For example, it is clear that Bratislava works with a much lower price range than other markets. If the range is larger in other markets, it means that businesses are more proactive in the price there, probably to increase their sales. Thanks to such a dynamic approach to price changes, the value of the coefficient of price elasticity is also relatively stable or rather more stable than on the Bratislava market. It can be argued that accommodation capacities in the Prague and Vienna markets respond more dynamically to consumer behaviour and thus do not result in such marked differences in changes in price elasticity of demand. Bratislava, as the only market surveyed, has also not reached occupancy levels as high as other markets in the long term. Again, this can only be a consequence of the aforementioned.

The research also points to the occurrence of a certain "November phenomenon", which describes the fact that the price elasticity of demand will change significantly in November, as will the average price and occupancy. This phenomenon has also been observed in previous years.

It is also necessary to mention what the three markets have in common. According to research, it can be argued that all three markets are associated with price inelastic demand for accommodation services. Although in some cases the coefficients fall into positive values or higher negative values, this is true from the point of view of mean values. In all three markets, we also observe Giffen's paradox of consumer behaviour, which is always reflected at the turn of the year.

All the above conclusions are presented on market data in the accommodation sector in three different destinations. These outputs can serve as an additional basis for examining such a wide-ranging problem as consumer behaviour in the markets, and they can also serve as a basis for companies to make use of price elasticity coefficients to optimise prices, which can lead to an increase in expected sales. 


\section{References}

Aalen, P., Iversen E.K., Jakobsen, E.W. (2019), Exchange rate fluctuations and demand for hotel accommodation: panel data evidence from Norway, "Scandinavian Journal of Hospitality and Tourism", 19 (2), pp. 210-225, https://doi.org/10.1080/15022 250.2018.1482566

Abrate, G., Nicolau, J.L., Viglia, G. (2019), The impact of dynamic price variability on revenue maximisation, "Tourism Management", 74, pp. 224-233, https://doi.org /10.1016/j.tourman.2019.03.013

Ahn, Y.-J., Baek, U., Lee, B.C., Lee, S.K. (2018), An almost ideal demand system (AIDS) analysis of Korean travelers" summer holiday travel expenditure patterns, "International Journal of Tourism Research", 20 (6), pp. 768-778, https://doi.org/10.1002/jtr.2229

Akbaba, A. (2006), Measuring service quality in the hotel industry: A study in a business hotel in Turkey, "International Journal of Hospitality Management", 25 (2), pp. 170-192, http://doi.org/10.1016/j.ijhm.2005.08.006

Assaf, A.G., Barros, C.P., Josiassen, A. (2010), Hotel efficiency: a bootstrapped metafrontier approach, "International Journal of Hospitality Management", 29 (3), pp. 468 475, https://doi.org/10.1016/j.ijhm.2009.10.020

Baldassin, L., Gallo, M., Mattevi, E. (2017), Tourism in European cities, “Tourism Economics", 23 (1), pp. 3-28, http://doi.org10.5367/te.2015.0494

Barros, C.P. (2005), Measuring efficiency in the hotel sector, "Annals of Tourism Research", 32 (2), pp. 456-477, https://doi.org/10.1016/j.annals.2004.07.011

Barros, C.P., Dieke, P. (2008), Technical efficiency of African hotels, "International Journal of Hospitality Management”, 27 (3), pp. 438-447, https://doi.org/10.1016/j.ijhm .2007 .11 .004

Dioko, L. (Don) A.N., So, S.-I. (Amy) (2012), Branding destinations versus branding hotels in a gaming destination - Examining the nature and significance of co-branding effects in the case study of Macao, "International Journal of Hospitality Management”, 31 (2), pp. 554-563, https://doi.org/10.1016/j.ijhm.2011.07.015

Dorta-Afonso, D., Hernández-Martín, R. (2015), Subnational tourism competitiveness performance. The Canary Islands vs. the German Länder, "European Journal of Tourism Research", 10, pp. 51-63.

Goolsbee, A., Petrin, A. (2004), The Consumer Gains from Direct Broadcast Satellites and the Competition with Cable TV, "Econometrica", 72 (2), pp. 351-381, https://doi .org/10.1111/j.1468-0262.2004.00494.x

Hsieh, L.F., Lin, L.H. (2010), A performance evaluation model for international tourist hotels in Taiwan - An application of the relational network DEA, "International Journal of Hospitality Management”, 29 (1), pp. 14-24, https://doi.org/10.1016/j.ij hm.2009.04.004

Ivanov, S., Ivanova, M. (2016), Do hotel chains improve destination's competitiveness?, „Tourism Management Perspectives”, 19 (A), pp. 74-79, https://doi.org/10.1016/j.tmp .2016 .04 .007

Ivanov, S., Webster, C. (2013), Globalisation as a driver of destination competitiveness, "Annals of Tourism Research", 43, pp. 628-633, https://doi.org/10.1016/j.annals.20 13.07.010 
Kim, H.B., Kim, W.G. (2005), The relationship between brand equity and firms" performance in luxury hotels and chain restaurants, "Tourism Management", 26 (4), pp. 549-560, https://doi.org/10.1016/j.tourman.2004.03.010

Mendieta-Peñalver, L.F., Perles-Ribes, J.F., Ramón-Rodríguez, A.B., Such-Devesa, M.J. (2016), Is hotel efficiency necessary for tourism destination competitiveness? An integrated approach, "Tourism Economics", 24 (1), pp. 3-26, https://doi.org/10 $.5367 /$ te. 2016.0555

Morlotti, C., Cattaneo, M., Malighetti, P., Redondi, R. (2017), Multi-dimensional price elasticity for leisure and business destinations in the low-cost air transport market: Evidence from easyJet, “Tourism Management”, 61, pp. 23-34, https://doi.org/10.10 16/j.tourman.2017.01.009

Nalley, M.E., Park, J., Bufquin, D. (2019), An investigation of AAA diamond rating changes on hotel performance, "International Journal of Hospitality Management", 77, pp. 365-374, https://doi.org/10.1016/j.ijhm.2018.07.016

Nunes, S., Estevão, C., Nicolau Filipe, M. (2018), Determinant factors of competitiveness in the hotel sector: the case of Portugal, "Competitiveness Review", 28 (2), pp. 122135, https://doi.org/10.1108/CR-07-2016-0043

Reynolds, D., Thompson, G.M. (2007), Multiunit restaurant productivity assessment using three-phase data envelopment analysis, "International Journal of Hospitality Management”, 26 (1), pp. 20-32, http://doi.org/10.1016/j.ijhm.2005.08.004

Sanjeev, G.M. (2007), Measuring efficiency of the hotel and restaurant sector: the case of India, "International Journal of Contemporary Hospitality Management", 19 (5), pp. 378-387, https://doi.org/10.1108/09596110710757543

Sánchez-Pérez, M., Illescas-Manzano, M.D., Martínez-Puertas, S. (2019), Modeling hotel room pricing: A multi-country analysis, "International Journal of Hospitality Management”, 79, pp. 89-99, https://doi.org/10.1016/j.ijhm.2018.12.014

Shy, O. (2008), How to Price: A Guide to Pricing Techniques and Yield Management, Cambridge University Press, Cambridge.

Sigala, M. (2004), Using data envelopment analysis for measuring and benchmarking productivity in the hotel sector, "Journal of Travel \& Tourism Marketing", 16 (2-3), pp. 39-60, https://doi.org/10.1300/J073v16n02_04

Tembi, M.T., Kimbu, A.N. (2019), Unlocking Policy Impediments for Service Delivery in Tourism Firms: Evidence from Small and Medium Sized Hotels in Sub-Saharan Africa, “Tourism Planning \& Development”, 16 (2), pp. 179-196, https://doi.org/10 $.1080 / 21568316.2018 .1556328$

Vives, A., Jacob, M., Aguiló, E. (2018), Online hotel demand model and own-price elasticities, “Tourism Economics", 25 (5), pp. 670-694, https://doi.org/10.1177/135481 6618800643

Wang, F.C., Hung, W.T., Shang, J.K. (2006), Measuring the cost efficiency of international tourist hotels in Taiwan, "Tourism Economics", 12 (1), pp. 65-85, https://doi .org/10.5367/000000006776387150

Xia, H., Vu, H.Q., Lan, Q., Law, R., Li, G. (2018), Identifying hotel competitiveness based on hotel feature ratings, "Journal of Hospitality Marketing \& Management”, 28 (1), pp. 1-20, https://doi.org/10.1080/19368623.2018.1504366 


\section{Zachowania konsumentów na rynku usług noclegowych - porównanie Wiednia, Bratysławy i Pragi w 2018 roku}

Celem artykułu jest porównanie trzech rynków usług noclegowych przy użyciu danych empirycznych pochodzących z ponad 250 obiektów noclegowych usytuowanych w trzech miejscowościach (Wiedeń, Bratysława, Praga). Na podstawie danych dziennych dokonano ich porównania dla okresów miesięcznych w 2018 roku. Porównania dokonano na podstawie trzech podstawowych kryteriów - obłożenia, średniej stawki dziennej oraz wskaźnika cenowej elastyczności popytu. Elastyczność cen zmierzono za pomocą analizy regresji log-log. Kluczowe wnioski z porównania są następujące: (1) Rynki wiedeński i praski są podobne pod względem obłożenia i współczynnika elastyczności cenowej. Z kolei rynek w Bratysławie wykazywał istotne statystycznie różnice w porównaniu z pozostałymi dwoma rynkami pod względem wszystkich badanych kryteriów. (2) Rynek w Bratysławie działał w znacznie niższym przedziale cenowym w porównaniu z innymi analizowanymi rynkami. W dłuższej perspektywie rynek ten charakteryzował się także mniejszym obłożeniem. (3) Rynki w Wiedniu i Pradze reagowały bardziej dynamicznie zmianą cen na zmiany w zachowaniu konsumentów. (4) Zidentyfikowano tak zwany „efekt listopada”, w którym wszystkie wskaźniki na wszystkich rynkach zachowywały się nietypowo. (5) Cechą wspólną wszystkich rynków jest to, że w długim okresie wykazywały one nieelastyczny cenowo popyt, a na przełomie roku wszystkie te kraje zmagały się z paradoksem Giffena.

Słowa kluczowe: usługi noclegowe, zachowania konsumentów, elastyczność cenowa, Wiedeń, Bratysława, Praga 